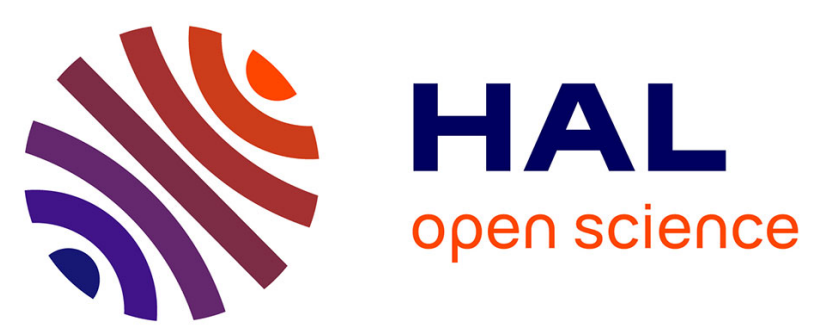

\title{
Use of SPOT4-VEGETATION satellite data to improve pasture production simulated by STICS included in the ISOP French system
}

C. Di Bella, Robert Faivre, Francoise Ruget, B. Seguin, M. Guérif, B. Combal, M. Weiss, C. Rebella

\section{To cite this version:}

C. Di Bella, Robert Faivre, Francoise Ruget, B. Seguin, M. Guérif, et al.. Use of SPOT4VEGETATION satellite data to improve pasture production simulated by STICS included in the ISOP French system. Agronomie, 2004, 24 (6-7), pp.437-444. 10.1051/agro:2004034 . hal-00886046

\section{HAL Id: hal-00886046 https://hal.science/hal-00886046}

Submitted on 1 Jan 2004

HAL is a multi-disciplinary open access archive for the deposit and dissemination of scientific research documents, whether they are published or not. The documents may come from teaching and research institutions in France or abroad, or from public or private research centers.
L'archive ouverte pluridisciplinaire HAL, est destinée au dépôt et à la diffusion de documents scientifiques de niveau recherche, publiés ou non, émanant des établissements d'enseignement et de recherche français ou étrangers, des laboratoires publics ou privés. 


\title{
Use of SPOT $_{4}$-VEGETATION satellite data to improve pasture production simulated by STICS included in the ISOP French system
}

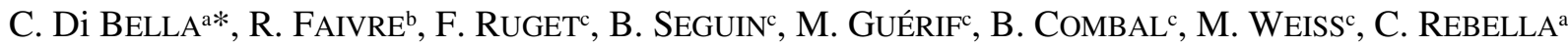 \\ ${ }^{a}$ Instituto de Clima y Agua - CIRN - INTA, Los Reseros y Las Cabañas S/N, Castelar (1712), Buenos Aires, Argentina \\ ${ }^{\mathrm{b}}$ Biométrie et IA, INRA, Toulouse, BP 27, 31326 Castanet-Tolosan Cedex, France \\ ${ }^{\mathrm{c}}$ CSE, Bâtiment Climat - INRA, Site Agroparc, 84914 Avignon Cedex 9, France
}

(Received 12 January 2003; accepted 11 June 2004)

\begin{abstract}
In France, pastures represent a significant land-cover type, which mainly sustains husbandry production. For this reason, it is of great benefit to develop real-time monitoring of pasture biomass production, taking into account its spatial and temporal variability. The absence of low-cost methods applicable to large regions has oriented French stakeholders to the use of growth simulation models adequately informed through spatialised databases (such as the ISOP system). Remote-sensing data may be considered a potential tool to improve simulations by objective observations in a real-time framework and the aim of this work was to evaluate this potential role of remote sensing. Thirteen forage regions (administrative partitioning of the French territory for pastures and grasslands) were selected in France, differing by their soil, climatic and land-cover characteristics. SPOT $_{4}$-VEGETATION satellite images $\left(1 \mathrm{~km}^{2}\right.$ resolution) were used to provide the spectral signature corresponding to pure pasture, using subpixel estimation methods. This information was then related to growth variables calculated by the STICS-pasture model (included in the ISOP system). We found that the best relations were obtained between a middle infrared-based vegetation index (SWVI) calculated from the elementary reflectance bands of the satellite, and the leaf area index (LAI) calculated from STICS. The use of these relations first showed the ability of satellite data to provide real-time estimations of growth status variables. Second, the comparison between both types of data showed that spatial and temporal differences existed between satellite and model information, mainly during the harvesting periods. This result could contribute to improving the model evaluations on a regional scale.
\end{abstract}

pastures / remote sensing / vegetation index / biomass production / STICS / regional scale

\section{INTRODUCTION}

The monitoring of pasture has a strategic impact on a national scale. For instance, it can allow the organisation of forage transfers between regions submitted to various drought conditions or the giving of objective elements for applying subsidy policies after extreme climatic events such as drought (the year 2003 is a good example). In fact, this kind of preoccupation is typical of national or European institutions (for example, the Central Service of Investigations and Statistical Studies in France-SCEES or the Joint Research Centre at the European Union level-JRC). However, the high spatial and temporal variability of pasture conditions, the small amount of readily available information, and the absence of forage economical traceability through specific markets, make it difficult to apply real-time alert systems to prairie production.

Some research groups are developing different methods to establish biomass production of pastures in a precise, economic and fast way. Biomass cutting is a simple method for estimating biomass production $[54,61]$ but this technique is limited by being time-consuming and costly, all the more because the amount of required measurements to produce a reliable evaluation at a national level is high. For these reasons, it is of great benefit to develop indirect techniques to estimate functional prairie features, such as biomass, net primary productivity (NPP) or leaf area index (LAI).

In recent years, growth simulation models have allowed methodological and operational progress in this domain. Pasture modelling has been the objective of different research groups [1, 18, 39, 47, 56, 62]. The STICS model developed at INRA [11] was adapted to pasture conditions by adding specific functions to simulate pasture characteristics [50]. The ISOP system (Information et Suivi Objectif des Prairies) was developed thanks to collaboration between INRA and MeteoFrance with the financial support of the SCEES. It consists of the STICS-pasture model properly connected to soil, climate and technical databases through a Geographical Information System. The ISOP system aims at estimating pasture growth variables, taking into account water and nitrogen budgets in order to identify water-deficient years as early as possible in the season as compared with a 16-year average. Current problems come less from the reliability of the model than from the input data variability to inform the forage regions or FR [16, $49,51]$. No actual validation has been possible because of the lack of existing ground truth data on this scale. 
Remote sensing offers interesting perspectives to enhance the achievements of simulation models, particularly the use of spatial and repetitive information provided by sensors with different spatial resolution. The use of remote sensing for prairie monitoring has been focused mainly on species and plant community identification $[6,15,26,33,36,55]$ and on surveying their geographical distribution [3, 22, 33, 42]. Also, several investigations have demonstrated the existence of a strong relationship between satellite information (principally from the NOAA-AVHRR satellite) and biomass or net primary productivity (NPP) for different regions and ecosystems worldwide $[10,12,23,27,40,41,43,53,63]$. Other studies have tried to identify drought periods or dry zones [57]. The major benefit of remote-sensing data lies in the possibility of getting spatially continuous information with a reasonable time period and cost. It also appears to be a unique tool for obtaining actual observations of crop status while models only offer a virtual estimation of it. It was decided to use VEGETATION sensor data (launched in April 1998 on the $\mathrm{SPOT}_{4}$ platform) in combination with outputs from the ISOP system to propose a national pasture survey in France. Therefore, the present work consists of exploring the possibilities of improving pasture productivity estimation at a regional resolution, by associating measurements provided by remote sensing and simulation results. In a first stage, we estimated pure pasture spectral responses from the radiometric information of pure pasture pixel at the resolution of $1 \mathrm{~km}^{2}$. After obtaining the spectral response of pure prairie for different dates and regions we submitted the satellite indicators of some biophysical variables, such as LAI or biomass, to estimation from the ISOP system using the STICS growth model. Finally, we analysed the possibilities offered by coupling the model and remote-sensing data.

\section{MATERIALS AND METHODS}

\subsection{Study areas}

The spatial resolution used in the ISOP system, also used in this work as the elementary model resolution, comes from an administrative partitioning of the French territory: the Forage Region (FR). In order to limit the work volume (the whole territory is covered by $200 \mathrm{FRs}$ ), we chose FRs representing most of the pasture production, climate and topography conditions (Fig. 1): 2503, 2505 and 2516 (Normandy Region); 4313 (High Jura Region); 7312 and 7315 (Southern France Pyrenees Region) and 8301, 8302, 8303, 8305, 8309, 8310 and 8311 (Central Plains Region). As far as remote-sensing resolution is concerned, each FR is characterised by a window of $25 \mathrm{~km}^{2}$ $\left(5 \times 5\right.$ pixels of $\left.1 \mathrm{~km}^{2}\right)$, and each window (pasture proportion and accompanying crop) is described in Table I.

\subsection{Satellite data and the subpixel estimation}

We used SPOT $_{4}$-VEGETATION sensor data acquired during 1999 and 2000. All these images were geo-referenced and co-registered in latitude/longitude projection. The data were received as $\mathrm{S}$ products (integrating available atmospheric corrections as 10-day synthetic data) [7, 45]. All images were received in HDF format (16 bits) and transformed into radio-

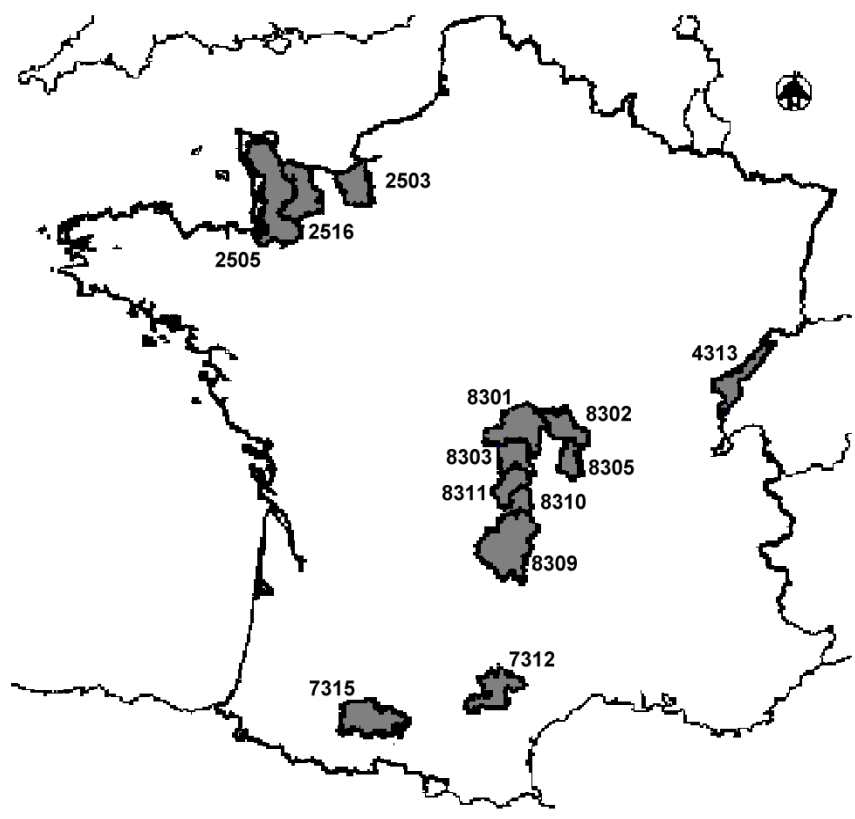

Figure 1. Thirteen forage regions (FR) selected as study areas in France.

Table I. Window characteristics inside each one of the selected FRs. $\mathrm{PP}=$ pasture proportion.

\begin{tabular}{lcc}
\hline FR & PP (\%) & AccompaNYING Crop / (\%) \\
\hline 2503 & 80 & Cultures complexes / 7 \\
2505 & 96 & Turbe / 2 \\
2516 & 85 & Complex Crops / 11 \\
4313 & 57 & Conifer Forests / 20 \\
7312 & 50 & Forests / 26 \\
7315 & 41 & Complex Crops / 35 \\
8301 & 69 & Complex Crops / 13 \\
8302 & 60 & Complex Crops / 16 \\
8303 & 54 & Complex Crops / 15 \\
8305 & 55 & Complex Crops 17 \\
8309 & 85 & Agriculture / 7 \\
8310 & 59 & Conifer Forests / 15 \\
8311 & 60 & Agriculture / 15
\end{tabular}

metric values, coded on 8 bits (0-255) (C ENVI 3.1). This treatment allowed us to reduce the file size and computing time as well. However, this transformation altered the original reflectance values while keeping the whole spatial and temporal dynamics.

In a $\mathrm{SPOT}_{4}$-VEGETATION image, every pixel integrates the spectral signatures of each land-cover type included in a pixel $\left(1 \mathrm{~km}^{2}\right)$. For the particular case of the VEGETATION sensor, this integration corresponds to a mean reflectance value in the blue $\left(\mathrm{B}_{0}\right)$, red $\left(\mathrm{B}_{2}\right)$, near-infrared $\left(\mathrm{B}_{3}\right.$ or NIR) and middle infrared ( $\mathrm{B}_{4}$ or $\left.\mathrm{MIR}\right)$ bands from the electromagnetic spectrum. This integration results in a mixed value representing many land-cover types. To recover the spectral response of a specific 
land-cover type, it is recommended to apply subpixel techniques, as described by several authors [8, 29, 44]. In France, Fischer [20] studied the temporal evolution of NDVI for pure cultures from mixed pixels while using an empiric model for all land use, assuming a double logistical function for the NDVI evolution. From the mixed spectral values and land use, it is possible to recover every double logistic parameter. Later, Kerdiles and Grondona [31] and Faivre and Fischer [19] assumed that the spectral variability within the mixed pixels was only due to land use. Using a linear model, every pure response was derived from the mixed reflectance, considering that the reflectance of a mixed pixel is the linear combination of the reflectance of each elementary pixel multiplied by its respective proportions within the pixel.

In order to achieve the pixel decomposition data from the SPOT $_{4}$-VEGETATION sensor data $(1 \mathrm{~km} \times 1 \mathrm{~km})$, corresponding to the window area, we adapted the model developed by Faivre and Fischer [19] with a specific programming format (C) Matlab). This model requires two types of input data to get pure spectral responses of every land-cover type inside a pixel of $1 \mathrm{~km}^{2}$ : (a) the proportion of each land-cover type per pixel, and (b) the reflectance values of mixed pixels in the different bands. Thus, for the 25 pixels selected from each FR (window), we firstly calculated the proportion of every land-cover type in the pixel, using the Corine Land Cover database (1989-1994). Secondly, for each pixel and date, we extracted the spectral data: $B_{0}, B_{1}, B_{2}, B_{3}$ and $B_{4}$. We generated the mean reflectance value for the different land uses in the pixel and the corresponding estimated variance as from these data, applying the subpixel estimation methodology, for every date and spectral band.

We tested the performance of several vegetation indices, using the spectral response of pure grassland estimations, as vegetation indices are not all as good for explaining structural and functional features of vegetation, such as green biomass and LAI $[4,9,21,25,35,58,65]$ as well as net primary productivity [34, 41]. Those indices are the NDVI, the SAVI (Soil Adjusted Vegetation Index, [28]) or PVI (Perpendicular Vegetation Index, [46]) that takes into account soil effects, and the SWVI (Middle Infrared-based NDVI, [13]) or the ARVI (Atmospherically Resistant Vegetation Index, [30]) that reduces the effects of atmospheric absorption (Tab. II). Linear and exponential-type relationships between the best index and the simulated LAI were then tested.

\subsection{STICS-pasture model and the ISOP system}

The ISOP system provides pasture productivity estimates on the Forage Region (FR) scale using the STICS simulation model [51] which simulates daily values of Leaf Area Index (LAI) in $\mathrm{m}^{2}$ leaf $\mathrm{m}^{-2}$ soil, standing biomass (MSEC), in $\mathrm{g}$ dry matter $\mathrm{m}^{-2}$ and dry matter Productivity (DMSEC $\mathrm{i}$ ) in $\mathrm{kg} \mathrm{ha}^{-1}$ day $^{-1}$ as growth variables of the system. Some stress indicators are also available as model output, such as the available soil water storage (RES) in $\mathrm{mm}$, and water and nitrogen-stress indices (TURFAC) and INNS as defined in [11]. The STICS model estimated those variables for the possible pasture management variables, fertilisation levels and soil types. The simulated value corresponding to each FR resulted from weighting all possible combinations considering their relative importance to the FR.
Table II. Vegetation Indices generated from the different spectral bands. $\mathrm{B}_{0}=$ blue band, $\mathrm{B}_{2}=$ red band, $\mathrm{B}_{3}=$ near-infrared band and $\mathrm{B}_{4}=$ middle infrared band.

\begin{tabular}{lcc}
\hline Index & Formula & Reference \\
\hline $\begin{array}{l}\text { NDVI } \\
\text { Normalised Difference }\end{array}$ & NDVI $=\frac{B 3-B 2}{B 3+B 2}$ & {$[48]$} \\
PVI & PVI $=\frac{(B 3-B 2 \times 1.2)}{\sqrt{1+1.2^{2}}}$ & {$[46]$} \\
Perpendicular Vegetation Index & SAVI $=\frac{(B 3-B 2)}{(B 3+B 2+0.5)}(1.5)$ & \\
SAVI & SWVI $=\frac{B 3-B 4}{B 3+B 4}$ \\
Soil Adjusted Vegetation Index & \\
SWVI & ARVI $=\frac{B 3-B 0}{B 3+B 0}$ \\
Middle Infrared-based NDVI & ARVI & {$[30]$} \\
Atmospherically Resistant & If the atmospheric factor is 1 & \\
Vegetation Index & \\
\hline
\end{tabular}

\subsection{Assimilation data}

The Monteith model [37] is one of the simplest and most popular models for assimilating remote-sensing data. In our study, this model, based on the concept of radiation-use efficiency, will allow the estimation of biomass productivity using different data sources: LAI provided by the STICS-pasture model or LAI estimated by remote-sensing data [2]. In this way, to estimate dry matter production for the day $\mathrm{j}\left(\mathrm{DMS}_{\mathrm{j}}\right.$ in $\left.\mathrm{g} \cdot \mathrm{m}^{-2}\right)$, we used the following algorithm (Fig. 2):

$$
\Delta M S_{j}=\varepsilon_{b} \times \varepsilon_{i j} \times \varepsilon_{c} \times G R_{j}
$$

where $G R_{j}$ is the global radiation $\left(\mathrm{MJ} \cdot \mathrm{m}^{-2}\right), \varepsilon_{c}$ stands for climatic efficiency (no units), $\varepsilon_{b}$ is the growth efficiency $\left(\mathrm{g} \cdot \mathrm{MJ}^{-1}\right)$ and $\left(\varepsilon_{i j}\right)$ is the intercepted radiation efficiency (no units). GR was obtained directly from meteorological weather stations reported by Meteo-France and interpolated to the FR scale for 1999 and 2000. The climatic efficiency value was fixed to 0.48 [64]. Growth efficiency, that was considered constant for long periods of time (season) and in non-limiting soil conditions [32], was set to 1.8 (g/MJPAR) for the whole growing season (February-October) [5, 17]. Finally, the intercepted radiation efficiency was indirectly estimated using LAI with a Beer-lawtype relationship [38]:

$$
\varepsilon_{i j}=\varepsilon_{i \max }\left(1-e^{-k L A I_{j}}\right)
$$

where $\varepsilon_{\mathrm{ij}}$ is the intercepted radiation, $\varepsilon_{\mathrm{imax}}$ is the maximal interception of $\varepsilon_{\mathrm{ij}}$ (no units), $k$ is the extinction coefficient $(0.55)$ and $L A I$ is the Leaf Area Index. In our case, the $L A I$ will be provided either by the STICS model ( $\left.L A I_{\text {isop }}\right)$ or by inversion of reflectance data $\left(L A I_{\mathrm{vgt}}\right)$.

\section{RESULTS}

We obtained the spectral response corresponding to pure pasture conditions inside each pixel (Fig. 3) using the subpixel 

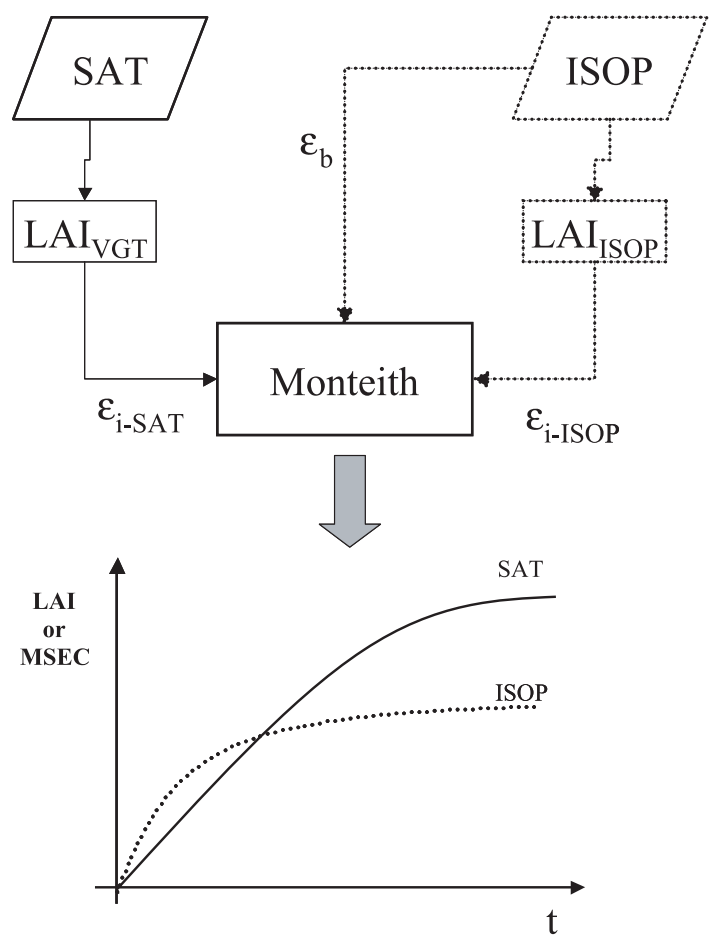

Figure 2. Schedule of assimilation procedure using remote-sensing data (SAT) or simulated growth data (ISOP).

model [19], for every FR and date. Comparing the different FRs, it is possible to evaluate the influence of prairie proportion and the type of accompanying crop inside each pixel. In general terms, all FRs showed a good correspondence in the temporal evolution of radiometric values of $\mathrm{B}_{3}$ between mean pixel values and those corresponding to the pure prairie estimations. However, depending on pasture proportion or the accompanying crops in the pixel, the subpixel estimations resulted in different seasonal spectral values.

Once we obtained the pure pasture conditions, and considering the set of variables obtained from the STICS-pasture simulation model, we found that LAI and MSEC were the best correlated to most satellite indices (Tab. III). These results, in agreement with Sellers [60], showed the potentiality of vegetation indices to describe vegetation status and, mainly, to join them to fluxes such as photosynthesis or net primary productivity. The SWVI vegetation index was the best correlated to growth estimations. The relationship of SWVI with LAI presented a correlation coefficient of 0.55 , and with MSEC of 0.40 , for a total of 594 cases, that showed the benefit of the MIR spectral band. This band not only corresponds to a sensible portion of water content in leaves, but also to dry matter content and leaf internal structure [14], showing (as a result) that SWVI is less sensitive than the NDVI to atmospheric effects. Another explanation could also be the one described by Guérif [24]. In that work, based upon the PVI, the PVI ${ }_{\text {mir }}$ calculated from the MIR band resulted in a better estimation of the LAI as compared with the PVI, calculated from the visible band $\left(\mathrm{PVI}_{\mathrm{vis}}\right)$. The
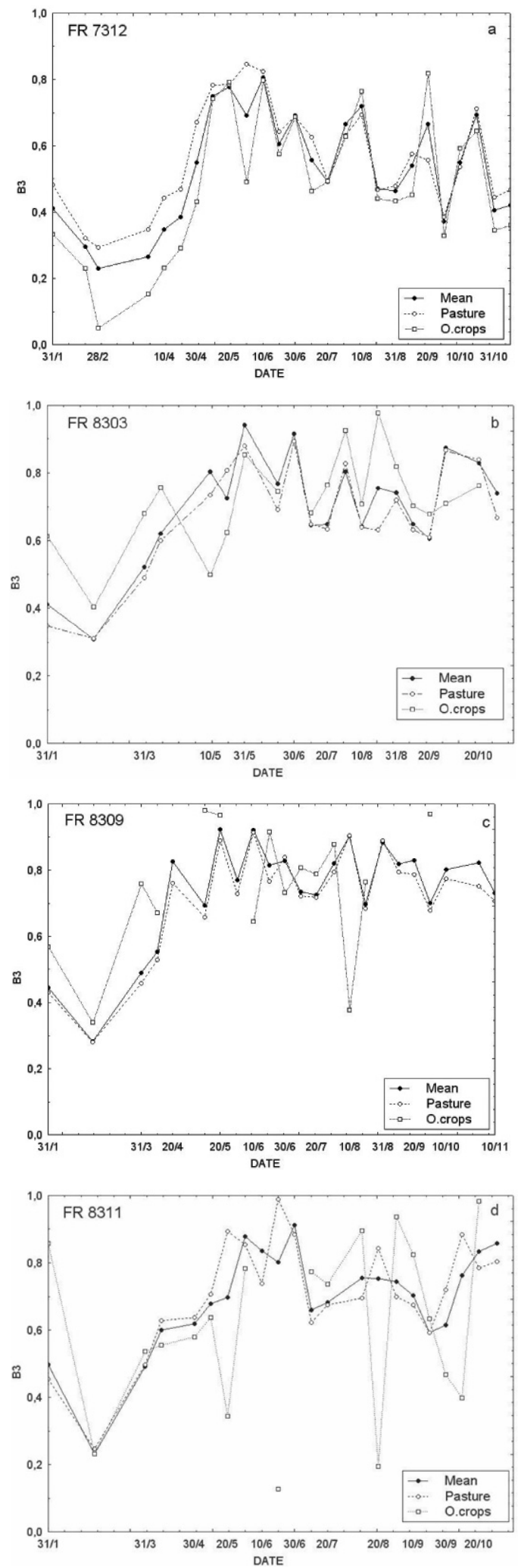

Figure 3. Evolution of the infrared values (digital counts) $\left(\mathrm{B}_{3}\right)$ during January-October 1999 for four forage regions (a: FR 7312; b: FR 8303; c: FR 8309 and d: FR 8311). (•) Mean values of the 25 pixels in each pilot zone; $(\bigcirc)$ pasture values estimated from the subpixel model; and ( $\square$ ) main accompanying crop. 
Table III. Correlation coefficients between satellite and production variables during the 1999 and 2000 experiments.

\begin{tabular}{|c|c|c|c|c|c|c|}
\hline SAT. / ISOP. & LAI & MSEC & RES & TURFAC & INNS & DMsec \\
\hline B0 & .1772 & .0114 & -.0568 & -.0793 & .0242 & -.0548 \\
\hline B2 & . 1581 & .0015 & -.1093 & -.1163 & -.0086 & -.0832 \\
\hline B3 & .4190 & .2299 & -.0673 & -.0667 & -.1261 & .0622 \\
\hline B4 & -.0417 & -.1146 & -.0539 & -.1041 & -.0293 & -.0699 \\
\hline NDVI & .0608 & .1626 & .1334 & .1130 & -.0435 & .1923 \\
\hline SWVI & .5540 & .4041 & -.0544 & .0060 & -.1208 & .1498 \\
\hline B3DB4 & .4289 & .3409 & .0107 & .0540 & -.1569 & .0977 \\
\hline SAVI & .3649 & .2633 & .0272 & -.0067 & -.1211 & .1494 \\
\hline PVI & .4283 & .2862 & -.0184 & -.0134 & -.1523 & .1276 \\
\hline ARVI & -.0253 & .1160 & .1231 & .1047 & -.0581 & .1403 \\
\hline
\end{tabular}

authors found that the $\mathrm{PVI}_{\mathrm{vis}}$ is considerably influenced by differences observed in chlorophyll concentration in the leaves.

After having established that the $S W V I$ vegetation index is the best descriptor of the biophysical variables characterising prairie production (LAI or MSEC), a general linear regression between SWVI and DMLAI allowed the establishment of the following linear function (Standard Deviation $=1.85, P<$ $0.005, \mathrm{R}^{2}=0.32$ ):

$$
L A I=3.256+6.141 \times S W V I
$$

which allows the derivation of LAI values from VEGETATION data. The comparison with LAI values produced by the ISOP model displayed an underestimation of lower values and an overestimation of higher ones. In order to improve this first attempt, an exponential relationship between vegetation indices and LAI was considered [25, 52, 59]. In a first approach, we defined a basic relation as:

$$
S W V I=S W V I_{\max }+\left(S W V I_{\min }-S W V I_{\max }\right) \mathrm{e}^{-k L A I}
$$

considering, for the first time, a $\mathrm{k}$ value of $0.55, \mathrm{SWVI}_{\min }$ of -0.357 and $\mathrm{SWVI}_{\max }$ of 0.828 (obtained from the database).

After using an iterative procedure to reduce the mean quadratic error for a total of 7005 cases during March-October 1999 and 2000, and keeping a maximal value for the $\mathrm{LAI}_{\text {isop }}$ of 8 and SWVI between 0.828 and -0.357 , we calculated the k value that minimises the sum of quadratic errors between $\mathrm{LAI}_{\mathrm{vgt}}$ and $\mathrm{LAI}_{\text {isop }}$ (Initial $\mathrm{k}$ of 0.55 ). The $\mathrm{k}$ value determined by this optimisation procedure $(\mathrm{k}=0.215)$ was therefore kept for the SWVI relation $=f(L A I)$. The application of this relation allowed the improvement of the linear relationship by increasing the internal data dynamics and decreasing the minimal LAI value during the winter period for the satellite values. In detail, it is also possible to observe, in the first place, that $\mathrm{LAI}_{\mathrm{vgt}}$ is different in both growing seasons; while this is not observed for the $\mathrm{LAI}_{\text {isop }}$ (Fig. 4). For both studied years and different FRs, the agreement between LAI estimations is highly variable (Fig. 4). At the beginning of the growing season, the LAI is underestimated by ISOP in Normandie (FR 2503) and Piémont Pyrénéen (FR 7315), and overestimated in one small area of the Central Plains (FR 8310). In the middle of spring (March to May), before the first cuts, the agreement is quite good. From June to September, the cuts do not occur exactly on the same date with both methods. Finally, by the year's end, especially in 1999, ISOP values are higher than those derived from satellite data. At the beginning of the growing season, the ISOP system assigned the same LAI values for all the areas, whatever the local climate. In this case, VEGETATION images can supply information to vary initial growth conditions between FRs.

Satellite information can also be useful to establish cutting dates, especially in areas smaller than the FR. In the ISOP system, these dates are only estimated as from grass management systems (e.g. hay and silage) and growing degree days between successive cuts, without taking into account rainy events delaying harvest, or local technical changes.

As from the established relation, it was possible to try a simple assimilation approach. LAI calculated from satellite data and the LAI values in the ISOP procedure were assimilated into the Monteith model. As a result, the daily production of MSEC was calculated for every FR and date during 2000. Figure 5 presents the difference between MSEC calculated from satellite data $\left(\mathrm{MSEC}_{\mathrm{vgt}}\right)$ and MSEC obtained from the STICS model within the ISOP system $\left(\mathrm{MSEC}_{\text {isop }}\right)$. This result confirmed that the SWVI/LAI relation could be applied to introduce the satellite information when it appears significant. While analysing the evolution of the differences between MSEC $_{\mathrm{vgt}}$ and $\mathrm{MSEC}_{\mathrm{isop}}$ values for the different FRs, there is a period in June with large differences in plain zones, especially in the Piémont Pyrénéen (FR 7315) and in mid-July, in the mountain zones (FR 8310 Fig. 5). The ISOP underestimation can proceed from poor attribution of pastures to soil types.

\section{CONCLUSIONS}

With the objective of elaborating an evaluation tool for grassland production, adapted to a regional scale, it was confirmed that the use of low spatial resolution sensors, such as VEGETATION, is promising. They deliver significant aggregated information with a high temporal resolution. The model developed by Faivre and Fischer [19], and adapted for the objectives of this work, proved to be a very useful and accurate tool for obtaining spectral responses, while taking into account the big spatial variability of information captured in the different wavelengths. It is important to notice that the usefulness of 

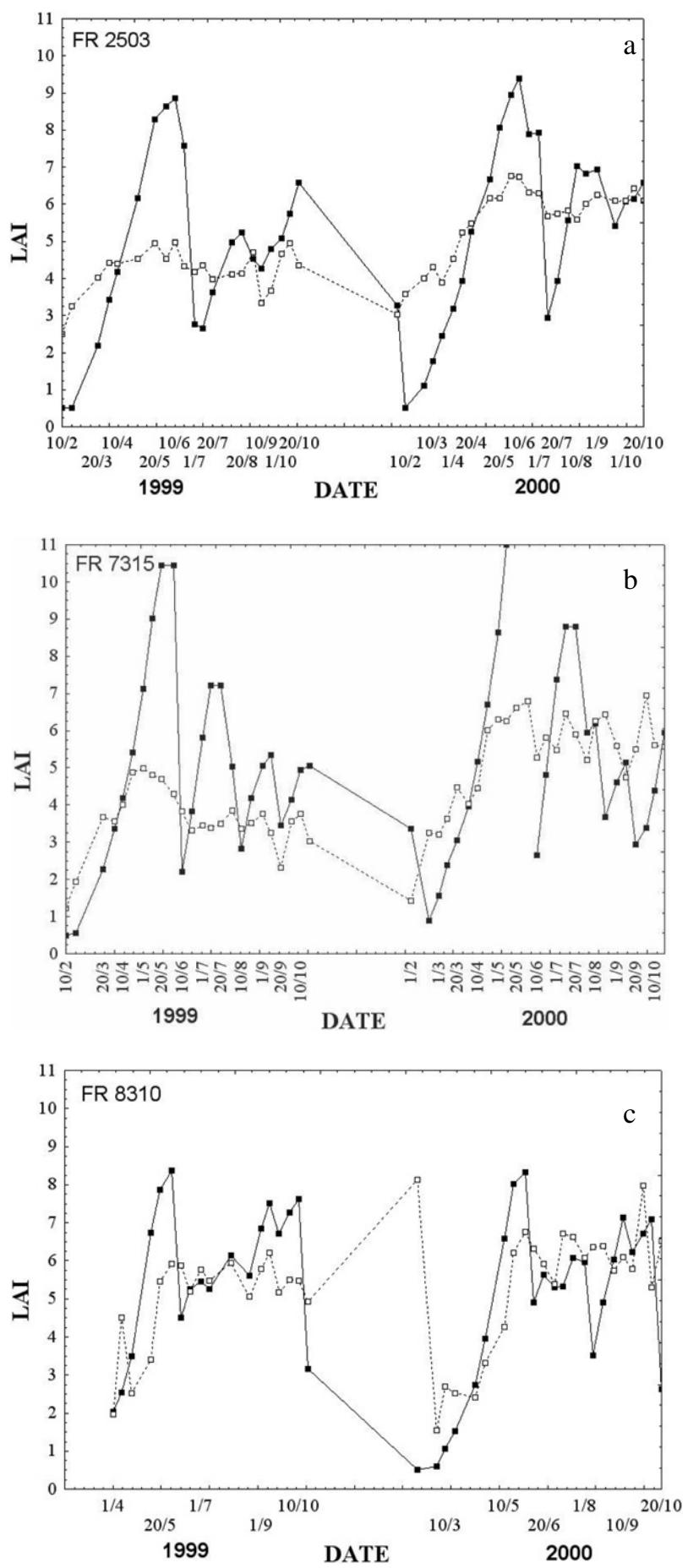

Figure 4. Temporal evolution of LAI estimated from satellite data (LAIVGT-dashed line) and LAI simulated by the STICS-pasture model (LAIISOP-continued line) for 1999 and 2000 for the FRs 2503, 7315 and 8303.

VEGETATION could be enhanced by the possibility of getting the same spectral information at high spatial resolution (10 metres with the HRV-SPOT sensor). This characteristic, which confers upon the VEGETATION sensor a unique advantage over other available sensors, was not tested in our study, but it could
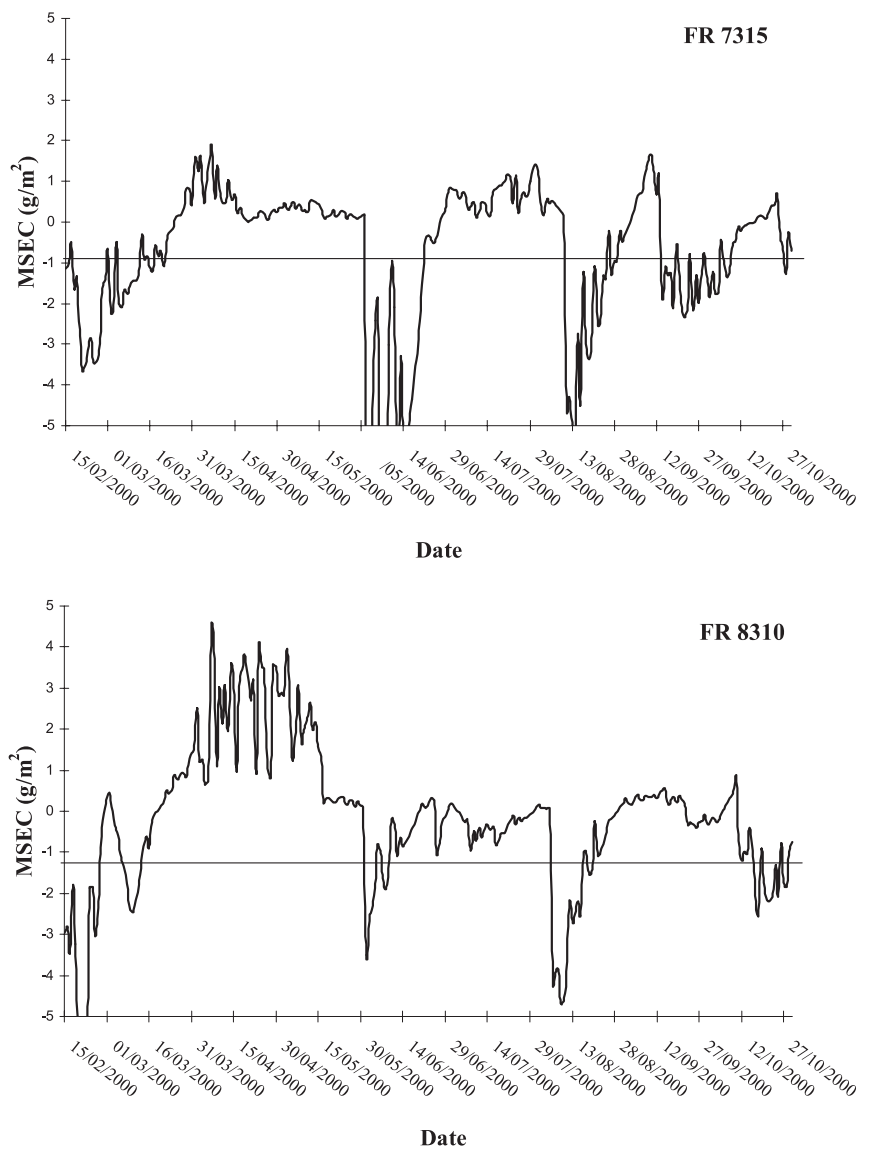

Figure 5. Temporal evolution of the difference between dry matter

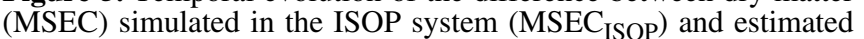

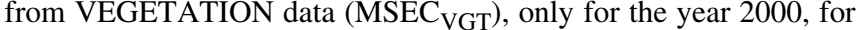
the FRs 7315 and 8310.

undoubtedly greatly increase the validity of pure pasture signatures.

Disaggregated information in the near-infrared and middle infrared bands corresponding to pure pasture conditions showed an acceptable correspondence with the temporary evolution of some productive variables such as the LAI and dry matter. This correspondence was improved appreciably by the calculation of vegetation indices, through band combination and normalisation of the strips that compose them (for example, SWVI). These interrelationships were significantly improved by applying an exponential function and selecting periods where temporary discordances do not exist within the model.

Satellite information, through its relationship to biophysical variables such as the LAI, gives a unique measure of the true dynamics of plant cover. Evaluations from satellite data agree with the model evaluations; however, some differences highlight some of the limits of a real-time framework. The forcing assimilation methods used in this paper allow the achievement of a real complementarity between remote sensing and the simulation model, and in the representation of annual dynamics (cutting and beginning of growth dates' representation). Also, more sophisticated methods, such as re-standardisation, would 
permit the estimation, region by region, of some STICS parameters using remote-sensing data, specially for the variables involving winter or cuts' re-growth (initial LAI), or the determination of cutting dates (sum of temperatures). Some divergences from the ISOP evaluations in relation to remote sensing could probably be attributed to the evaluation of some input variables (for example, soil water reserve).

Finally, it is important to highlight that even if remote sensing could not be considered as a direct reference for validation, the results obtained make the usefulness of this kind of information evident on a local scale, as well as the potentialities for the development of a combination method between the model and remote-sensing data.

Acknowledgements: This work represents the final part of Carlos M. Di Bella's Doctoral Thesis at the INA-PG (Paris-France). It has been financed by INTA (Argentina) and INRA (France). We want to thank specially the important suggestions of the editors.

\section{REFERENCES}

[1] Arnold G.W., Campbell N.A., A model of a farming system, with particular reference to a sub-model for animal production, Proc. Aust. Soc. Anim. Prod. 9 (1972) 23-30.

[2] Asrar G., Fuchs M., Kanemasu E.T., Hatfield J.L., Estimation absorbed photosynthetic radiation and leaf area index from spectral reflectance in wheat, Agron. J. 76 (1984) 300-306.

[3] Azzali S., Menenti M., Mapping vegetation-soil-climate complexes in southern Africa using temporal Fourier analysis of NOAAAVHRR NDVI data, Int. J. Remote Sens. 21 (2000) 973-996.

[4] Baret F., Guyot G., Potentials and limits of vegetation indices for LAI and APAR assessment, Remote Sens. Environ. 35 (1990) 161173.

[5] Bélanger G., Gastal F., Lemaire G., Growth analysis of a tall fescue sward fertilized with different rates of nitrogen, Crop Sci. 32 (1992) 1371-1376.

[6] Benoit M., Girard Cm., De Vaubernier E., Comparaison du comportement spectral de prairies permanentes en Lorraine avec leur type d'utilisation, Agron. 8 (1988) 265-272.

[7] Berthelot B., Dedieu G., Correction of atmospheric effects for VEGETATION data, in: G.a.P. Guyot T. (Ed.), Physical Measurements and Signatures in Remote Sensing, Courchevel, France, 1997, pp. 19-25.

[8] Bierwirth P.N., Mineral mapping and vegetation removal via datacalibrated pixel unmixing, using multispectral images, Int. J. Remote Sens. 11 (1990) 1999-2017.

[9] Bouman B.A.M., Accuracy of estimating the leaf area index from vegetation indices derived from crop reflectance characteristics, a simulation study, Int. J. Remote Sens. 13 (1992) 3069-3084.

[10] Box E.O., Holben B.N., B, V., Accuracy of the AVHRR vegetation index as a predictor of biomass, primary productivity and net $\mathrm{CO}_{2}$ flux, Vegetation 80 (1989) 71-89.

[11] Brisson N., Mary B., Ripoche D., Jeuffroy M.H., Ruget F., Nicoullaud B., Gate P., Devienne-Barret F., Antonioletti R., Dürr C., Richard G., Beaudoin N., Recous S., Tayot X., Plénet D., Cellier P., Machet J.-M., Meynard J.M., Delécolle R., STICS: a generic model for the simulation of crops and their water and nitrogen balances. I. Theory and parametrization applied to wheat and corn, Agronomie 18 (1998) 311-346.
[12] Burke I.C., Kittel T.G.F., Lauenroth W.K., Snook P., Yonker M., Parton W.J., Regional analysis of the Central Great Plains, Bioscience 41 (1991) 685-692.

[13] Cayrol P., Chehbouni A., Kergoat L., Dedieu G., Mordelet P., Nouvellon Y., Grassland modeling and monitoring with $\mathrm{SPOT}_{4}$ VEGETATION instrument during 1997-1999 SALSA experiment, Agric. For. Meteorol. 105 (2000) 91-115.

[14] Ceccato P., Flasse S.,Grégoire J.-M., Designing a spectral index to estimate vegetation water content from remote sensing data. Part II: Validation and application, Remote Sens. Environ. 82 (2002) 198-207.

[15] Chaneton E., Di Bella C., León R., Rebella C., Análisis regional de la variabilidad espacial y temporal de la productividad primaria de los pastizales de la Pampa Deprimida, XVII Reunion Argentina De Ecología (1995) Mar del Plata, Buenos Aires, Argentina.

[16] Donet I., Ruget F., Rabaud V., Pérarnaud V., Delécolle R., Bonneviale N., Isop: An integrated system to real-time assessment of forage production variability over France, the 4th European Conference on Applications of Meteorology (ECAM 99) Norrköping, Sweden, 13-17 September, 1999.

[17] Duru M., Ducrocq H., Tirilly V., Modelling growth of cocksfoot (Dactylis glomerata L.) and tall fescue (Festuca arundinacea Schreb.) at the end of spring in relation to herbage nitrogen status, J. Plant Nutr. 18 (1995) 2033-2047.

[18] Edelstein P.R., Newton J.E., Treacher T.T., A model of ewes with lambs grazing at pasture, Internal Rep. No. 260, Grassland Research Institute, Hurley, Berks, UK, 1973.

[19] Faivre R., Fischer A., Predicting crop reflectances using satellite data observing mixed pixels, J. Agric. Biol. Environ. Stat. 2 (1997) 87-107.

[20] Fischer A., A simple model for the temporal variations of NDVI at regional scale over agricultural countries. Validation with ground radiometric measurements, Int. J. Remote Sens. 15 (1994) 14211446 .

[21] Gilabert M.A., Gandía S., Meliá J., Analyes of spectral-biophysical relationships for a corn canopy, Remote Sens. Environ. 55 (1996) 11-20.

[22] Girard C.M., Rippstein G., Utilisation de données SPOT HRV pour la cartographie de savanes et pâturages dans les Llanos de Colombie, Bul. SFPT 133 (1994) 11-19.

[23] Goward S.N., Tucker S.J., Dye D.G., North American vegetation patterns observed with the NOAA-7 advanced very high resolution radiometer, Vegetation 64 (1985) 3-14.

[24] Guérif M., Machet J.M., Droulin J.F., Utilisation de la télédétection pour caractériser le statut azote des cultures de betteraves sucrières, 58th Congress - French Technical Institute for Sugar Beet, 19 June, 1995, Bruxelles, Belgium.

[25] Hatfield J.L., Kanemasu E.T., Arara G., Jackson R.D., Pinter P.J., Reginato R.J., Idso S.B., Leaf area estimates from spectral measurements over various dates of wheat, Int. J. Remote Sens. 6 (1985) 167-175.

[26] Hobbs R.J., Remote Sensing of Spatial and Temporal Dynamics of Vegetation, in: Remote Sensing of Biosphere Functioning, Hobbs R.J., Mooney H.A. (Eds.), 1990, Chap. 10, pp. 203-219.

[27] Hobbs T.J., The use of NOAA-AVHRR NDVI data to assess herbage production in the arid rangelands of Central Australia, Int. J. Remote Sens. 16 (1995) 1289-1302.

[28] Huete A.R., A soil-adjusted vegetation index (SAVI), Remote Sens. Environ. 25 (1988) 295-309.

[29] Jasinski M.F., Estimation of Subpixel Vegetation Density of Natural Regions Using Satellite Multispectral Imagery, IEEE Trans. Geosci. Remote Sens. 34 (1996) 804-813. 
[30] Kaufman Y.J., Tanré D., Atmospherically Resistant Vegetation Index (ARVI) for EOS-MODIS, IEEE Trans. Geosci. Remote Sens. 30 (1992) 261-270.

[31] Kerdiles H., Grondona M., NOAA-AVHRR NDVI descomposition and subpixel classification using linear mixing in the Argentinean Pampa, Int. J. Remote Sens. 16 (1995) 1303-1325.

[32] Laguette S., Utilisation des données NOAA-AVHRR pour le suivi du blé a l'échelle de l'Europe, Doctoral Thesis, ENGREF, Paris, 1997.

[33] Lauver C.L., Mapping species diversity patterns in the Kansas shortgrass region by integrating remote sensing and vegetation analysis, J. Veg. Sci. 8 (1997) 387-394.

[34] Law B.E, Warning R.H., Combining remote sensing and climatic data to estimate net primary production across Oregon, Ecol. Appl 4 (1994) 717-728.

[35] Lo Seen D., Mougin E., Rambal S., Gaston A., Hiernaux P., A regional Sahelian grassland model to be coupled with multispectral satellite data. II: Toward the control of its simulations by remotely sensed indices, Remote Sens. Environ. 52 (1995) 194206.

[36] Lobo A., Moloney K., Chiariello N., Fine-scale mapping of a grassland from digitized aerial photography: An approach using image segmentation and discriminant analysis, Int. J. Remote Sens. 19 (1998) 65-84.

[37] Monteith J.L., Solar radiation and productivity in tropical ecosystems, J. Appl. Ecol. 19 (1972) 747-766.

[38] Monteith J.L., Climatic variation and the growth of crops, Q. J. Roy. Meteorol. Soc. 107 (1981) 749-774.

[39] Parton W.J., Scurlock J.M.O., Ojima D.S., Schimel D.S., Hall D.O., Scope Program Group Members. Impact of climate change on grassland production and soil carbon worldwide, Global Change Biol. 1 (1995) 13-22.

[40] Paruelo J.M., Epstein H.E., Lauenroth W.K., Burke I.C., ANPP estimates from NDVI for the central grassland region of the US, Ecology 78 (1997) 953-958.

[41] Paruelo J.M., Oesterheld M., Di Bella C.M., Arzadum M., Lafontaine J., Cahuepé M., Rebella C.M., Estimation of primary production of sub-humid rangelands from remote sensing data, Appl. Veg. Sci. 3 (2000) 189-195

[42] Peterson U., Aunap R., Changes in agricultural land use in Estonia in the 1990s detected with multitemporal Landsat MSS imagery, Landscape and Urban Planning 41 (1998) 193-201.

[43] Prince S.D., Satellite remote sensing of primary production: comparison of results for Sahelian grasslands 1981-1988, Int. J. Remote Sens. 12 (1991) 1301-1311.

[44] Puyou-Lascassies P., Flouzat G., Gay M., Vignolles C., Validation of the use of Multiple Linear Regression as a Tool for Unmixing Coarse Spatial Resolution Images, Remote Sens. Environ. 49 (1994) 155-166.

[45] Rahman H., Dedieu G., SMAC: A Simplified Method for the Atmospheric Correction of Satellite Measurements in the Solar Spectrum, Int. J. Remote Sens. 15 (1994) 123-143.

[46] Richardson A.J., Wiegand C.L., Distinguishing vegetation from soil background information, Photogramm. Eng. Remote Sens. 43 (1977) 1541-1552.

[47] Riedo M., Grub A., Rosset M., Fuhrer J., A pasture simulation model for dry matter production, and fluxes of carbon, nitrogen, water and energy, Ecol. Model. 105 (1998)141-183.

[48] Rouse J.W., Haas R.W., Schell J.A., Deering D.W., Harlan J.C., Monitoring the vernal advancement and retrogradation (Greenwave effect) of natural vegetation. NASA/GSFCT Type III Fina Report, Greenbelt, MD, USA, 1974.
[49] Ruget F., Delécolle R., Tiers N., Rabaud V., Duru M., Gastal F., Donet I., Estimating alarm situations on grassland production at regional scale, 7th ICCTA, Computer Technology in Agricultural management and risk prevention, Firenze, Italia, 15-18 November 1998, abstract, $130 \mathrm{p}$.

[50] Ruget F., Duru M., Gastal F., Adaptation of an annual crop model (STICS) to a perennial crop: grassland, International symposium modeling cropping systems, 21 June 1999, Lleida, Spain, pp. 111112.

[51] Ruget F., Delécolle R., Le Bas C., Duru M., Bonneviale N., Rabaud V., Donet I., Pérarnaud V., Paniagua S., L'estimation régionale des productions fourragères, Colloque Ager-Mia, 31 August 2000, in: Modélisation des agroécosystèmes et aide à la décision, CiradINRA (Ed.), Montpellier, Collection Repères, Malézieux, Trébuil, Jaeger Ed., pp. 263-282.

[52] Running S.W., Nemani R.R., Relating seasonal patterns of the AVHRR vegetation index to simulated photosynthesis and transpiration of forests in different climates, Remote Sens. Environ. 24 (1988) 347-367.

[53] Running S.W., Estimating Terrestrial Primary Productivity by Combining Remote Sensing and Ecosystem Simulation, in: Remote Sensing of Biosphere Functioning, Hobbs R.H., Mooney H.A. (Eds.), 1990, Chap. 4.

[54] Sala O.E., Parton W.J., Joyce L.A., Lauenroth W.K., Primary Production of the central grassland region of the United States, Ecology 69 (1988) 40-45.

[55] Salami A.T., Vegetation dynamics on the fringes of lowland humid tropical rainforest of south-western Nigeria-an assessment of environmental change with air photos and Landsat TM, Int. J. Remote Sens. 20 (1999) 1169-1181.

[56] Saugier B., Ripley E.A., Lueke P., Modelling: VIII. A mechanistic model of plant growth and water use for the Matador grassland. Technical Report, Matador Project, University of Saskatchewan, 1974, No. 65, 96 p.

[57] Seguin B., NOAA/AVHRR data for crop monitoring at a regional level: Possibilities and limits in the European Context. EARSel Advances, Remote Sens. 2 (1993) 87-93.

[58] Sellers P.J., Canopy reflectance, photosynthesis and transpiration, Int. J. Remote Sens. 6 (1985) 1335-1372.

[59] Sellers P.J., Canopy reflectance, photosynthesis and transpiration. II. The role of biophysics in the linearity of their interdependence, Remote Sens. Environ. 21 (1987) 143-183.

[60] Sellers P.J., Berry J.A., Collatz C.B., Field C.B., Hall F.G., Canopy reflectance, photosynthesis and transpiration. III. A reanalysis using improved leaf models and a new canopy integration scheme, Remote Sens. Environ. 42 (1992) 187-216.

[61] Sims P., Singh J.S., Lauenroth W.K., The structure and function of ten western North American grassland, J. Ecol. 66 (1978) 251285.

[62] Thornley J.H.M., Cannell M.G.R., Temperate grassland responses to climate change: an analysis using the Hurley pasture model, Ann. Bot. 80 (1997) 205-221.

[63] Tucker C.J., Vanpraiet C.L., Sharman M.J., Van Ittersum G., Satellite remote sensing of total herbaceous biomass production in the Senegalese Sahel, Remote Sens. Environ. 17 (1985) 233-249.

[64] Varlet-Grancher C., Bonhomme R., Chartier M., Artis P., Efficience de la conversion energetique de l'energie solaire par un couvert vegetal, Acta Oecol. Oecol. Plant. 3 (1982) 3-26.

[65] Wiegand C.L., Richardson A.J., Nixon P.R., Spectral components analysis: A bridge between spectral observations and agrometeorological crop models, IEEE Trans. Geosci. Remote Sens. 24 (1986) 83-89. 